\title{
US Influence and a Caribbean Post-Colonial State
}

\section{Geoff Lamb}

Many of the recent discussions of the nature of the post-colonial State have had very little to say about the potential effect on the State of popular political struggles. In contrast, the conventional theories, with which radicals are often explicitly taking issue, have been very much preoccupied with the problem of whether mass struggles could be accommodated, contained or controlled within the governmental apparatuses erected in the terminal colonial period. The "erosion of the democratic ideal", in Donal Cruise O'Brien's words, consisted of a declining conviction among Western social scientists in the 1960 s in the resilience and effectiveness of pluralist ideologies and institutions in this regard in the 'new nations', and their displacement by commitments to technologism and authoritarianism.

Recent critical theorising, on the other hand, has been concerned to emphasise the connections between foreign domination and the national state apparatuses, via the analysis of continued (and transformed and often intensified) foreign economic penetrations, and of the political and social character of the comprador forces in local political control. This is a crucially important task: but the political effects of resting the analysis there are clear. Firstly, there is a tendency to represent the resulting contradictions as being between 'national' and 'international' systems-a tendency which, in the case of so-called dependency theories, is no ideological accident; secondly, it produces a kind of radical pessimism, often coupled with a voluntaristic and highly idealised advocacy of 'revolution'. The discussion below may serve to make this point, albeit in a very summary form, since it concentrates on the complex outcomes of intense domestic political conflicts for states from a region which is almost archetypally imperialist-dominated. There should be no need to add, of course, that 'domestic' politics here means political struggles within determinate social formations, but struggles whose forms and movement reflect the nature of the particular insertion of these formations into the capitalist world.

The Caribbean as a whole has been going through intense crisis in recent years. The outward signs are obvious enough: rapid economic and social decline in the small plantation and monocrop islands; the conversion of Puerto Rico, despite its relative 'development', into an apparently endemically stagnant appurtenance of American capital; decline of tourism and demand for mineral exports because of the world recession; and bigh and rising unemployment and inflation, coupled with declining possibilities of emigration to the industrial cores. 1 . The extreme example of crisis and decline is provided by Grenada, where real income per head declined by one-third in 1974 alone, and where the only significant economic question, in the words of a militant of the heavily repressed New Jewel Movement, is whether the island is in fact owned by Venezuela or by the Mafia.

It is not only in the smaller and poorer islands, however, that the rhythms of crisis have been marked by sharply defined political outcomes: those parts of the region such as Trinidad, Guyana and Jamaica, where productive forces are relatively more highly developed and where there exist large and organised working classes, are also the countries where the most evident political changes are taking place.

Trinidad and Guyana, in fact, present an interesting contrast in this regard. Both are classified as 'More Developed Countries' in the context of the Caribbean Community; both depend on a combination of mineral and agricultural exports (oil and sugar in the case of Trinidad, bauxite and sugar in the case of Guyana); both have roughly the same population (around 1,000,000) with fairly equal racial division between people of African and Indian origin. Both countries too have had very close connections with American power. The Burnham government's origin, as is well known, lay in CIA-supported strikes and racial upheavals in the early 1960 s which displaced the government of Cheddi Jagan, and Burnham's regime has for years been widely regarded as operating under a guarantee of American (and Venezuelan) power. In Trinidad, the People's National Movement government of Eric Williams was initially less overtly US sponsored-indeed in the pre-Independence period Williams' campaign against the US military base on the island was taken as a sign of anti-Ameri.

1 A recent, though over-optimistic, brief survey of a maj-r part of the region is provided in E. Hodgkinson, ed.. Development Prosnects and Ontions in the Commonwealth Caribbean, ODI (Loncion) 1976. 
canism'-but has certainly since the earlv 1960s actively encouraged American investment, and functions as a conservative force in the Caribbean region as a whole. It was not surprising, therefore, that in the first major test of Williams' strength after Independence-the so-called black power rebellion of 1970-American naval forces were on hand should the need have arisen.

But the effect of popular struggles in recent years has been to push Guyana steadily away from the imperial umbrella, while the Trinidadian regime has apparently huddled closer under it. The explanation for this disparity would certainly repay systematic investigation: the purpose of pointing to the contrast here, however, is to emphasise Trinidad's different status in the imperial chain in the Caribbean. Guyana's nationalisation policy in recent years was in part a measure of persistent mass support for Jagan and the People's Progressive Party, repression and systematic electoral fraud notwithstanding: it may also be seen, however, as a not undesirable disvestment, from the viewpoint of the bauxite and sugar companies-and thus a recognition by the Burnham regime of the internal and external logic of a move down the 'non-capitalist road'. Trinidad, however, occupies a more 'privileged' place in the Caribbean/US context, as will become clearer.

That 'privileged' position held by Trinidad intensified working class struggles against the regime and against foreign companies, while in Guyana strikes and working class rumblings, particularly those which seemed set to challenge the existing racially based political dispositions, thrust the regime steadily, from the early 1970 s onwards, to the point where its structural relations with US and British capital were altered in important respects, opening up new political possibilities.

The Trinidadian situation after the onset of the 'oil crisis' in 1973 produced what the earlier popular rebellion in 1970 had failed to do: it laid the basis, however fragile, for a racially united working class challenge to the post-colonial order. The basis for this intensification of political and economic struggle has been very quickly grasped by trade unionists and working class political militants. The combined effect of inflation/recession on a world scale and massive increases in Trinidadian oil revenue (and, to a much smaller extent, sugar proceeds) was the threat of substantial deterioration in the position of both employed workers and the reserve army of the unemployed, but great opportunities of accumu- lation for the components of the dominant political alliance-big foreign capital, domestic entrepreneurs and rentiers, and the neo-colonial pettybourgeoisie in particular-with the State playing a critical distributive role. Although it is true that a substantial proportion of organised labour (particularly those in state employment) remains, through the Trade and Labour Congress, committed to the PNM Government, the country's crucial unions-in oil, sugar, transport and sections of manufacturing services and construction-have come under the political aegis of the United Labour Front.

The ULF had its birth in the upheavals in the cane fields and the sugar industry in Trinidad in early 1975. The regeneration of the sugar workers' union and a strong drive to organise small cane farmers in conditions of rising world sugar prices resulted in a strike to wrest better terms from the State and the sugar factories which coincided with a prolonged strike by oil workers aginst Texaco in particular. This political union of oil and sugar workers not only created a serious industrial situation for the companies and the regime: it also presented a fundamental challenge to the bourgeois-dominated racial parties which drew much of their electoral support from the Afro-Trinidadian and Indian working classes respectively. The oil and sugar workers' strikes and the cane farmers' 'no cutting' campaign ended on less than favourable terms after the Government had declared a state of emergency, had mobilised troops to run the factories and transport petroleum products, and had even, with the agreement of Texaco, 'nationalised' the company's domestic filling stations in order legally to facilitate strike-breaking by the military.

The experience, nevertheless, had been of overwhelming importance. From the early 1950s, political movements in Trinidad had been based on carefully cultivated racial hierarchies, spearheaded by national bourgeois and petty-bourgeois leaderships. That pattern is still evidently predominant in the 'Negro' ideological character of the PNM, and no ULF leader would claim that it is not still a problematic factor in the allegiances of the ULF's working-class supporters. Nevertheless, the union of oil and sugar (i.e. an alliance between the two politically critical elements of the Afro-Trinidadian and Indian working classes respectively) had demonstrated the ULF's viability sufficiently for the party to be in effect re-mobilised politically early in 1976. With a more elaborate political programme and organisational structure, in Septem- 
ber last year the movement displaced the racial parties and fringe groupings which contested the Trinidad elections, to emerge as the major opposition to the PNM.

The ULF had thus, despite its youth and evident vulnerability, achieved an extraordinary objective in Trinidadian political conditions. The incorporated, racial discourse of the neo-colonial polity, with its formal nationalism and substantive subservience, its emphasis on the racial control of the petty spoils of independence, had been displaced by an ideology which specifically identifies anti-imperialism as the key to its political strategy, with the United States seen as the primary target and chief ally (through the agency of the petroleum-linked multinationals in particular) of the Williams Government. The possibilities of political change in Trinidad, therefore, would seem to rest almost entirely within the forces represented by the ULF, ambiguous though some of its political components and tendencies might as yet be.

The State itself has passed through the populist phase of neo-colonial integration, and consolidated itself as a structure with extensive involvement in directly productive enterprises (mainly of junior-partner, infrastructural or declining kinds) and with comprehensive control functions for American capital. Two important points should be noted here: (a) 'American capital' is overwhelmingly dominated by investment in the petroleum industry, notably by two oil majorsTexaco (land-based production and refining) and Amoco (off-shore production). (b) The Trinidad State is of growing importance in 'regional' affairs as a political and economic intermediary for foreign capital in the Caribbean as a whole. This role serves not only (or even primarily) the oil companies but particularly the large number of multinationals which have established a manufacturing or trading capacity in Trinidad with the object of penetrating the entire market of the Caribbean and northern Latin American littoral; it also serves, let it be said, the 'stabilising' political interests of American capital in the region in general.

The outcome of the crisis in the first place, therefore, has been to emphasise the hegemony of American capital within the Trinidad State and to underline the subordinate status of 'national capital' in the dominant political alliance. A recent and telling illustration of this relation was provided in the sharp struggle over Trinidad's currency policy. Despite strong attempts by national capital from 1973 onwards to unhook the Trinidad dollar from sterling and hence halt its downward spiral against the US dollar, this decision was delayed until May 1976. The effect of the delay, of course, was severely inflationary, given the very high import content of dollar origin. From the point of view of the oil companies, however, the effect was greatly to cheapen costs of production, particularly since a substantial part of oil and natural gas development work incurs substantial local costs, and is handled by sub-contracting systems using local labour and construction contractors. From the point of view of the State it meant the accumulation of vast US dollar balances, since taxes and royalties, like oil prices, are calculated and paid in US dollars: this also provided the wherewithal for an appearance of Government beneficence to counter the huge increases in consumer prices by well-publicised subsidies for a range of essential foodstuffs and other commodities.

More significant in the longer run, however, is the fact that the effect of the crisis has been to accelerate the development of a political force-the ULF - which is not only a direct response to intensified exploitation of working people, but also represents the first major possibility since the labour struggles of the 1930s of a decisive challenge to the pattern of foreign control of the Trinidadian economy.

Trinidad may present an untypically clear case, given the extensive proletarianisation of its population and advanced stage of working class political and economic organisation. Nevertheless, it demonstrates rather clearly that such mass political struggles are not merely factors to be read off from a 'core-periphery' relation which is in fact conceived as a capital-capital one, but are instead the means whereby the principal contradiction between capital and peripheral societies is expressed. In particular, Trinidad, and the intriguing Guyanese comparison, also illustrate the manner in which the state apparatus is itself modified by the movement of that contradiction. 